\title{
PERTUMBUHAN DAN PERKEMBANGAN ANAK PENDERITA PENYAKIT GINJAL KRONIK
}

\author{
(CHILD GROWTH AND DEVELOPMENT WITH \\ CHRONIC KIDNEY DISEASE)
}

\author{
Dian Erlianda, Mochamad Fahlevi Rizal \\ Departemen Ilmu Kedokteran Gigi Anak \\ Fakultas Kedokteran Gigi, Universitas Indonesia \\ E-mail: dianerlianda@gmail.com
}

\begin{abstract}
Chronic kidney disease (CKD) in children is a health problem in the world. Children with CKD at RSCM (Rumah Sakit Cipto Mangunkusumo) on 1991-1995 there were 1533 children and in 1996-2000 the cases increased 13.3\%. Clinical manifestations of CKD are retarded growth, malnutrition, anemia, fluid and electrolyte imbalance that can cause a defect in the bone, tooth enamel and delay of eruption. Systemic conditions such as bleeding tendency, anemia, defect and growth retardation child with CKD are important variables to consider a comprehensive treatment plan in pediatric dentistry. This paper discuss the role of kidney and CKD effect on the growth and development of children. Children with CKD showed growth retardation that caused impaired kidney function as excretory and endocrine organ. Kidney damage causes the body loss fluid balance, acid-base in the blood and mineral salt that are essential for growth. Kidney damage causes metabolic acidosis which causes impaired secretion of growth hormone, anemia, loss of appetite (cachexia) and reduced production of active vitamin $\mathrm{D}$ resulting in growth retardation. In conclusion, children with $\mathrm{CKD}$ showed impaired growth, malnutrition, anemia hypertension, imbalance electrolyte and body fluid, therefore it can be visible defect in bone and tooth enamel and also delay eruption of the tooth.
\end{abstract}

Key words: chronic kidney disease, growth and development

\begin{abstract}
Abstrak
Penyakit ginjal kronik (PGK) pada anak merupakan masalah kesehatan yang di dunia. Jumlah anak penderita PGK di RSCM (Rumah Sakit Cipto Mangunkusumo) tahun 1991-1995 adalah sebanyak 1533 anak dan pada tahun 1996-2000 terdapat peningkatan kasus sebesar 13,3\%. Manifestasi klinis PGK pada anak dapat berupa gangguan pertumbuhan, malnutrisi, ketidakseimbangan cairan dan elektrolit sehingga dapat menyebabkan defek pada tulang, email gigi dan pertumbuhan gigi yang terlambat. Kondisi sistemik seperti kecenderungan perdarahan, anemia, defek dan keterlambatan pertumbuhan gigi anak PGK merupakan variabel penting dalam mempertimbangkan rencana perawatan yang komprehensif di bidang kedokteran gigi anak. Makalah ini membahas peran ginjal dan efek PGK terhadap pertumbuhan dan perkembangan anak. Anak dengan PGK menunjukkan keterlambatan pertumbuhan yang dapat disebabkan oleh gangguan pada fungsi ginjal sebagai organ ekskretorik dan hormonal. Ginjal yang rusak menyebabkan tubuh kehilangan keseimbangan cairan, asam basa di dalam darah dan garam mineral yang penting untuk pertumbuhan. Kerusakan ginjal menyebabkan asidosis metabolik dan gangguan sekresi hormon pertumbuhan, anemia, penurunan nafsu makan (kaheksia) dan berkurangnya produksi vitamin D aktif sehingga menyebabkan keterlambatan pertumbuhan. Sebagai kesimpulan, anak dengan PGK menunjukkan gangguan pertumbuhan, malnutrisi, anemia, hipertensi, ketidakseimbangan elektrolit dan cairan tubuh, sehingga mungkin terlihat defek pada tulang dan email gigi, serta pertumbuhan gigi-geligi yang terlambat.
\end{abstract}

Kata kunci: penyakit ginjal kronik, pertumbuhan dan perkembangan

\section{PENDAHULUAN}

Penyakit ginjal kronik (PGK) atau chronic kidney disease (CKD) didefinisikan sebagai abnormalitas struktur ginjal dengan atau tanpa penurunan laju filtrasi glomelurus (LFG) selama minimal tiga bulan. ${ }^{1-}$ ${ }^{3}$ Seorang anak dapat dikatakan menderita PGK apabila terdapat satu atau lebih gejala berupa abnor- 
malitas komposisi urin, abnormalitas pemeriksaan pencitraan dan abnormalitas biopsi ginjal selama minimal 3 bulan, walaupun tanpa penurunan $\mathrm{LFG}^{4}{ }^{4}$ Penyakit ginjal kronik merupakan terminologi baru yang dikeluarkan oleh The National Kidney Foundation's Kidney Disease and Outcome Quality Initiative pada tahun 2002. Terminologi ini dibuat untuk mempermudah komunikasi antara dokter, pasien dan keluarganya, serta memperoleh prevalensi stadium awal yang akurat, deteksi dini dan mengetahui progresivitas penyakit.

Penyakit ginjal kronik (PGK) merupakan masalah kesehatan yang cukup tinggi di seluruh dunia. Prevalensi di dunia diperkirakan sekitar $8-16 \% \%^{5,6} \mathrm{Di}$ Amerika Serikat, prevalensi PGK pada anak dilaporkan kira-kira 18,5-58,3 per satu juta anak, sedangkan di Eropa sebanyak 9,7 per satu juta penduduk pertahun. ${ }^{2,3,5}$ Di Jepang, pada tahun 1998, di-temukan prevalensi gagal ginjal terminal pada anak sebanyak 22 per sejuta populasi. ${ }^{3}$ Prevalensi PGK pada anak di Indonesia yang bersifat nasional belum ada. Pada penelitian di 7 rumah sakit pendidikan dokter spesialis anak di Indonesia pada tahun 1984-1988 ditemukan 2.889 anak yang dirawat dengan penyakit ginjal. Pada tahun 1991-1995 di Rumah Sakit Cipto Mangunkusumo (RSCM) Jakarta terdapat 1.533 anak PGK dan pada tahun 1996-2000 terdapat peningkatan kasus sebesar 13,3\%. Secara spesifik kasus PGK stadium 3 dan 4 di RSCM menurut data tahun 20042012 mengalami peningkatan kasus. ${ }^{2,7}$ Data lain dari Rumah Sakit Hasan Sadikin Bandung tahun 1994998 terdapat 55 kasus PGK sementara di tahun 2000-2003 hanya ditemukan sebanyak 20 kasus. ${ }^{24}$

Manifestasi klinis PGK pada anak dapat berupa gangguan pertumbuhan, malnutrisi, anemia, hipertensi, ketidakseimbangan elektrolit dan cairan tubuh sehingga mungkin terlihat defek pada tulang dan email gigi, serta pertumbuhan gigi-geligi yang terlambat. ${ }^{8,9}$ Kondisi sistemik seperti hipertensi, kecenderungan perdarahan, anemia, defek pada jaringan keras gigi dan keterlambatan pertumbuhan gigi pada anak PGK merupakan variabel yang penting dalam mempertimbangkan rencana perawatan yang komprehensif di bidang kedokteran gigi anak. Makalah ini akan membahas peran ginjal dan efek PGK terhadap pertumbuhan dan perkembangan anak.

\section{Fungsi Ginjal dalam Pertumbuhan dan Perkembangan Anak}

Ginjal berperan dalam homeostasis tubuh dengan mengatur volume, komposisi elektrolit dan asam basa dalam darah serta dengan mengeliminasi produk sisa metabolisme. Mekanisme fungsi ginjal melibatkan filtrasi sejumlah besar cairan di glomerulus, di- ikuti dengan proses rearbsorpsi dan eksresi di sepanjang nefron. Nefron yang rusak akan berdampak pada perubahan ekskresi dan metabolik yang akhirnya akan berpengaruh pada keseluruhan fungsi organ tubuh. ${ }^{1,5,10}$

Ginjal normal memelihara homeostasis dengan menjaga komposisi cairan ekstraseluler dan elektrolit seperti natrium, kalium, fosfor dan kalsium. ${ }^{10,11}$ Fungsi utama natrium adalah untuk menjaga dan mengatur tekanan osmotik agar cairan tidak keluar dari darah dan masuk ke dalam sel. Natrium juga berperan dalam absorpsi glukosa dan sebagai transportasi zat gizi melalui membran sel. Natrium bekerja sama dengan kalium yang memiliki peranan penting dalam metabolisme energi yaitu sebagai katalisator dalam sintesis protein sel. ${ }^{1,10,11}$ Kalsium dan fosfor di dalam darah diperlukan dalam pertumbuhan tulang yang normal. Kalsium dan fosfor bertanggung jawab terhadap proses mineralisasi tulang dan gigi. Kelebihan fosfor dalam darah akan dieliminasi oleh ginjal sehingga tetap tercipta keseimbangan kalsium dan fosfor dalam darah. Apabila ginjal rusak, kadar fosfor akan meningkat di dalam darah dan menyebabkan kalsium keluar dari tulang sehingga tulang menjadi rapuh. ${ }^{3,11}$

Peran ginjal dalam menghasilkan vitamin D aktif (1,25-dihydroxycholecalciferol) sangat penting untuk metabolisme kalsium di dalam tulang. Vitamin D aktif membantu tulang menyerap kalsium dalam jumlah yang tepat dari darah. ${ }^{1,3,11,12}$ Penurunan fungsi ginjal dapat menyebabkan gangguan sekresi vitamin D aktif sehingga penyerapan kalsium tidak optimal. ${ }^{11,12}$

Keseimbangan cairan, elektrolit dan asam basa di dalam darah akan membuat tubuh mampu memproduksi hormon pertumbuhan. ${ }^{10,11}$ Hormon pertumbuhan (growth hormone) adalah hormon yang diproduksi oleh kelenjar pituitari dan diperlukan selama masa kanak-kanak untuk merangsang pertumbuhan baik jaringan lunak maupun jaringan keras. Hormon ini akan memberikan informasi ke organ hati untuk menghasilkan hormon lain yaitu insulin-like growth factor (IGF) yang kemudian akan memberi sinyal ke otot, tulang dan organ-organ lain untuk tumbuh melalui proses proliferasi dan diferensiasi sel. ${ }^{11,12}$

Ginjal, selain berperan sebagai organ ekskresi, memiliki fungsi endokrin. Ginjal berperan dalam proses eritropoiesis dengan memproduksi suatu zat yang disebut faktor eritropoietik yang mengubah proeritropoietin menjadi eritropoietin. Eritropoietin merupakan hormon yang menstimulus sumsum tulang (bone marrow) untuk memproduksi sel darah merah yang secara normal jumlahnya diatur oleh ginjal. ${ }^{3,10,12}$ 


\section{Penyakit Ginjal Kronik pada Anak}

Penyakit ginjal kronik adalah abnormalitas struktur maupun fungsi ginjal yang tidak reversibel setidaknya selama 3 bulan atau lebih, dengan atau tanpa penurunan LFG. Penyakit ginjal ini bersifat progresif dan dapat diketahui dari pemeriksaan darah, urin, pemeriksaan pencitraan, radiologi dan biopsi ginjal. $^{2,4}$

Berdasarkan Kompendium Nefrologi Anak Indonesia dan National Kidney Foundation - the Kidney Disease Outcomes Quality Initiative (NKF-K/DOQI), PGK diklasifikasikan menjadi 5 tahap atau stadium (Tabel 1). Stadium 1 yaitu apabila LFG masih dalam batas normal LFG $\left(90 \mathrm{ml} / \mathrm{min} / 1,73 \mathrm{~m}^{2}\right)$ dengan adanya tanda kerusakan ginjal seperti kelainan komposisi darah atau urin, kelainan radiologis atau kelainan biopsi ginjal, stadium 2 kerusakan ringan dengan LFG $60-89 \mathrm{ml} / \mathrm{min} / 1,73 \mathrm{~m}^{2}$, stadium 3 yaitu kerusakan sedang dengan LFG 30-59 ml/min/1,73m , kemudian stadium 4 yaitu kerusakan parah dengan LFG $15-29 \mathrm{ml} / \mathrm{min} / 1,73 \mathrm{~m}^{2}$, sedangkan stadium 5 sudah ditetapkan sebagai gagal ginjal (established renal failure) dengan LFG $<15 \mathrm{ml} / \mathrm{min} / 1,73 \mathrm{~m}^{2}$ atau sedang terapi dialisis. ${ }^{1,2,4}$

Tabel 1. Pembagian stadium ginjal berdasarkan penurunan laju filtrasi glomerulus

\begin{tabular}{|c|c|c|}
\hline Stadium & $\begin{array}{c}\text { LFG } \\
\left(\mathrm{mL} / \text { menit/ }^{2}\right. \\
\left.1,73 \mathrm{~m}^{2}\right)\end{array}$ & Deskripsi \\
\hline 1 & $>90$ & $\begin{array}{l}\text { Kerusakan ginjal dengan LFG } \\
\text { normal / meningkat }\end{array}$ \\
\hline 2 & $60-89$ & $\begin{array}{l}\text { Kerusakan ginjal dengan penurunan } \\
\text { LFG ringan }\end{array}$ \\
\hline 3 & $30-59$ & $\begin{array}{l}\text { Kerusakan ginjal dengan penurunan } \\
\text { LFG sedang }\end{array}$ \\
\hline 4 & $15-29$ & $\begin{array}{l}\text { Kerusakan ginjal dengan penurunan } \\
\text { LFG parah }\end{array}$ \\
\hline 5 & $\begin{array}{l}<15 \text { (atau } \\
\text { dialisis) }\end{array}$ & Gagal ginjal \\
\hline
\end{tabular}

Individu dengan LFG normal diikutsertakan dalam definisi PGK karena kerusakan ginjal sering terjadi sebelum penurunan fungsi ginjal dan individu tersebut berisiko menderita PGK di masa yang akan datang. Oleh karena itu, individu dengan LFG $<60 \mathrm{ml} / \mathrm{meni} / 1,73 \mathrm{~m}^{2}$ tanpa kerusakan ginjal dimasukkan ke dalam definisi PGK karena sudah terdapat penurunan fungsi ginjal mencapai 50\% dibawah normal dan ditemukan peningkatan prevalensi anak dengan komplikasi PGK. ${ }^{2}$

Penyakit ginjal kronik dikaitkan dengan berbagai perubahan fisiologis dan metabolisme yang kompleks seperti penurunan fungsi bahkan kegagalan ginjal, akumulasi toksik uremik yang disebut ure- mia, metabolisme asidosis, kelainan pada lipid, asam amino, mineral, metabolisme tulang serta malnutrisi, resistensi insulin, inflamasi, anemia, kekurangan vitamin $\mathrm{D}$, disfungsi otot rangka, massa tubuh tanpa lemak dan kaheksia. ${ }^{13,14}$

Manifestasi klinis PGK dapat berupa gangguan nutrisi, anemia, hipertensi, kelainan tulang, gangguan elektrolit dan cairan. Anak dengan penyakit ginjal cenderung menunjukkan keterlambatan pertumbuhan (perawakan pendek), kulit berwarna coklat pucat, tampak lemah dan cenderung mudah mengalami memar serta perdarahan paska pembedahan, sementara di dalam rongga mulut mukosa tampak pucat, terkadang ditemukan petekie atau pigmentasi mukosa mulut, stomatitis uremik, glossitis, inflamasi gingiva, hipoplasia enamel dan erupsi gigi yang terlambat. ${ }^{1,7,8,14,15}$ Anak terdiagnosis PGK mempengaruhi perluasan dan lokasi defek pada gigi-geligi anak tersebut. ${ }^{8,15,16}$

\section{Efek Penyakit Ginjal Kronik Terhadap Pertumbuhan dan Perkembangan Anak}

Anak dikatakan gagal bertumbuh apabila berada di bawah persentil ketiga atau dibawah 2 SDS (standar deviasi) berat dan tinggi badan rata-rata menurut usia dan jenis kelamin yang sesuai pada lebih dari satu kali pengamatan. Pemeriksaan dilakukan dengan menentukan angka pada garis horisontal yang menandakan usia dan menentukan angka pada garis vertikal yang menandakan tinggi atau berat badan. Hubungkan angka pada garis horisontal dan angka pada garis vertikal hingga mendapatkan titik temu (plotted point). Titik temu ini merupakan gambaran perkembangan anak berdasarkan kurva pertumbuhan WHO. Pemeriksaan ideal untuk hal ini adalah menggunakan grafik pertumbuhan sesuai etnis setiap anak (Gambar 1). ${ }^{11,16,17}$
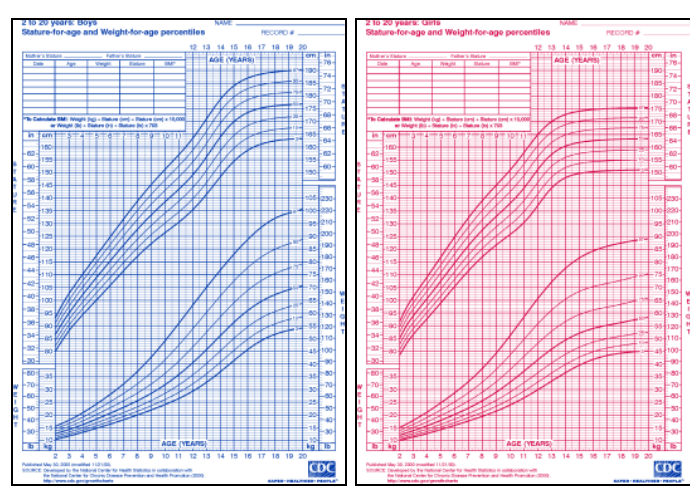

Gambar 1. Grafik tinggi badan dan berat badan anak lakilaki dan perempuan usia 2-20 tahun $^{16}$ 
Ginjal yang rusak dapat memperlambat pertumbuhan anak salah satunya melalui gangguan keseimbangan asam basa, nutrisi dan mineral di dalam darah, seperti kalium, natrium, kalsium dan fosfor. ${ }^{9-11} \mathrm{Ke}-$ tidakmampuan ginjal untuk mengeksresikan ion $\mathrm{H}^{+}$ mengakibatkan terjadinya asidosis metabolik dengan ditandai penurunan $\mathrm{pH}$ dalam plasma. ${ }^{5}$ Asidosis metabolik dapat menyebabkan degradasi protein dan menurunkan produksi hormon pertumbuhan dari kelenjar pituitari. Pada keadaan ini reseptor hormon pertumbuhan yaitu IGF mengalami penurunan konsentrasi. Berkurangnya konsentrasi IGF menyebabkan pertumbuhan sel menjadi terhambat. ${ }^{12}$

Pengeluaran urin yang berlebihan atau poliuria berkontribusi menyebabkan gangguan keseimbangan cairan tubuh sehingga anak mengalami kehilangan mineral. ${ }^{11}$ Anemia merupakan masalah yang umum pada pasien PGK dengan prevalensi $31 \%$ pada stadium 1 dan 93,3\% pada stadium 4. Anemia menyebabkan kelemahan, berkurangnya kekebalan tubuh, penurunan aktifitas dan kognitif. Anemia pada PGK disebabkan oleh defisiensi eritropoietin dan zat besi. Pada kondisi ini, anak tidak memiliki cukup sel darah merah yang sehat untuk membawa oksigen ke sel-sel di seluruh tubuh, sehingga dapat menyebabkan kerusakan jaringan sehingga pertumbuhan menjadi terhambat., ${ }^{2,12,15}$

Penurunan nafsu makan, kehilangan darah kronik akibat pengambilan darah yang sering untuk proses evaluasi rutin, proses hemodialisis dan masa hidup eritrosit yang memendek menyebabkan anak mengalami defisiensi zat besi. ${ }^{2}$ Seorang anak dengan PGK mungkin merasa tidak lapar atau tidak memiliki energi untuk makan, hal ini menyebabkan gizi buruk dan pertumbuhan menjadi terlambat. Penurunan selera makan dipengaruhi oleh peningkatan hormon leptin dan adiponektin. ${ }^{11-13}$ Keadaan ini juga dikenal sebagai sindrom anoreksia-kaheksia yaitu kumpulan gejala yang ditandai dengan anoreksia, penurunan berat badan, kehilangan massa otot, gangguan metabolisme dan disertai kelemahan. ${ }^{14}$

Telah ditemukan suatu protein pembawa sinyal yang disekresi oleh jaringan adiposa seperti leptin, adiponektin dan hormon usus yaitu ghrelin juga terlibat dalam patogenesis anoreksia-kaheksia dan fungsi metabolisme. Kaheksia berhubungan dengan proses katabolisme yang berkepanjangan dan berkaitan dengan aksi mediator inflamasi seperti tumor necrosis$\alpha(\mathrm{TNF}-\alpha)$, interleukin-1 $\beta$ (IL-1 $\beta)$, interleukin-6 (IL$6)$. Pada pasien PGK cenderung rentan terhadap infeksi sehingga memungkinkan banyaknya mediator inflamasi yang dilepaskan yang dapat menimbulkan keadaan kaheksia. ${ }^{3,14}$

Sebagai hormon yang disekresi oleh jaringan adi- posa dan dieksresi di ginjal menyebabkan kadar leptin serum pasien PGK meningkat. ${ }^{18,19}$ Hiperleptinemia memegang peranan penting dalam patogenesis komplikasi pada pasien PGK seperti kaheksia, kerusakan kardiovaskular, inflamasi kronis, resistensi insulin dan komplikasi tulang. ${ }^{18}$ Leptin diketahui dapat menurunkan asupan makanan melalui sistem neuroendokrin dengan cara melewati sawar darah otak kemudian menuju ke hipotalamus. ${ }^{20}$ Studi epidemiologi menyatakan bahwa peningkatan kadar leptin serum menyebabkan penurunan asupan makanan sehingga berkontribusi dalam perkembangan malnutrisi protein. ${ }^{19-21}$

\section{PEMBAHASAN}

Keterlambatan pertumbuhan dan perkembangan anak PGK melibatkan beberapa faktor dan dipengaruhi oleh tingkat kerusakan ginjal. Namun demikian, tidak semua anak PGK mengalami kegagalan pertumbuhan dan belum diketahui dengan pasti penyebabnya. Anak dibawah usia 5 tahun yang menderita PGK mempunyai risiko kegagalan pertumbuhan yang lebih besar dibanding usia onset PGK saat sudah remaja. ${ }^{12,15}$ Tidak seperti orang dewasa yang telah menyelesaikan pematangan fisiologis dan intelektual mereka, bayi dan anak-anak pada tahap awal proses perkembangan mereka sangat rentan terhadap efek samping dari PGK. Bukti yang ditemukan di Chili menunjukkan bahwa pasien PGK memiliki keterlambatan pertumbuhan sebesar 50\% dan di RSCM Jakarta 56\% anak PGK memiliki postur yang pendek. ${ }^{7,11}$

Keterlambatan pertumbuhan dan perkembangan dapat terlihat ketika kondisi ginjal rusak, toksik sisa metabolisme menumpuk di dalam darah yang disebabkan gangguan fungsi tubulus dan ginjal tidak dapat memprioritaskan fungsi hormon pertumbuhan dengan optimal. $^{3,11}$

Terdapat penelitian yang menyebutkan bahwa leptin dapat menghambat pembentukkan tulang melalui penyampaian serotonin dari batang otak ke hipotalamus. Walaupun di dalam penelitian lain fungsi leptin kontradiksi dengan hal tersebut di atas. Pada studi in vitro leptin memiliki efek osteogenik atau pembentukan tulang yang dimediasi oleh suatu reseptor di osteoblast, osteoklas, kondrosit sehingga terjadi mineralisasi. ${ }^{19,21}$ Oleh sebab itu, peran leptin di dalam proses pertumbuhan dan perkembangan khususnya anak dengan PGK perlu mendapat perhatian untuk mengetahui proses pertumbuhan dan perkembangan yang terjadi.

Sebagai kesimpulan, anak dengan PGK menunjukkan gangguan pertumbuhan, malnutrisi, anemia, hipertensi, ketidakseimbangan elektrolit dan cairan tu- 
buh sehingga mungkin terlihat defek pada tulang dan email gigi, serta pertumbuhan gigi-geligi yang terlambat. Keterlambatan pertumbuhan dapat disebabkan oleh gangguan pada fungsi ginjal sebagai organ ekskretorik dan hormonal. Ginjal yang rusak menyebabkan tubuh kehilangan keseimbangan cairan, asam basa di dalam darah, dan garam mineral yang

\section{DAFTAR PUSTAKA}

1. Fitzpatrick JJ, Wilson MHMN, McArdle SL. Renal disease and chronic renal failure in dental practice. $\mathrm{J}$ Ir Dent Assoc. 2008; 54(5): 215-8.

2. Pardede SO, Chunnaedy S. Penyakit ginjal kronik pada anak. Sari Pediatr. 2009; 11(3): 199-203.

3. Noer MS. Gagal Ginjal Kronik Pada Anak (Chronic Renal Failure in Children). Div Nefrol Anak Bagian Ilmu Kesehat Anak. <https://id.scribd.com/doc / 39256594/gagal-ginjal> (Maret 16, 2014).

4. Noer MS, Soemyarso NA, Subandiyah K, Prasetyo $\mathrm{RV}$, Alatas H, Tambunan T, et al. Kompendium nefrologi anak. Jakarta: Badan Penerbit IDAI; 2011: 215-21.

5. Jha V, Garcia G, Iseki K, Li Z, Naicker S. Chronic kidney disease: global dimension and perspectives. Lancet. 2013; 382 (9888): 260-72.

6. Warady BA, Chadha V. Chornic kidney disease in children: the global perspective. Pediatr Nephrol. 2007; 22(12): 1999-2009.

7. Chunnaedy S, Pardede SO, Djer MM. Karakteristik dan kesintasan penyakit ginjal kronik stadium 3 dan 4 pada anak di Departemen Ilmu Kesehatan Anak FKUI-RSCM. IDAI (Indonesia Pediatr Soc.) 2013; 16(2): 71-8.

8. Haider SR, Tanwir F, Momin IA. Oral aspects of chronic renal failure. Pakistan Oral Dent J. 2013; 33(1): 87-9.

9. Seraj B, Ahmadi R, Ramezani N, Mashayekhi A, Ahmadi M. Oro-Dental health status and salivary characteristics in children with chronic renal failure. $\mathrm{J}$ of Dentistry of Tehran University of Medical Sciences 2011; 8(3): 146-52.

10. Sheerwood L. Human Physiology: From Cells to Systems. $8^{\text {th }}$ ed., Belmont: Brooks Cole, 2012; 492-6.

11. Janjua HS, Mahan DJ. Growth failure in children with chronic kidney disease. Adv Chronic Kidney Dis. 2013; 18(5): 324-31.

12. Salas P, Pinto V, Rodriguez J, Zambrano MJ, Mericq V. Growth Retardation in Children with Kidney Disease. Int J of Endocrinology 2013; 2013 (970946): 1-7. penting untuk pertumbuhan. Kerusakan ginjal menyebabkan asidosis metabolik yang menyebabkan gangguan sekresi hormon pertumbuhan, anemia, penurunan nafsu makan (kaheksia) dan berkurangnya produksi vitamin $\mathrm{D}$ aktif sehingga menghasilkan keterlambatan pertumbuhan.

13. Alix, Pascaline M, Guebre-Egziabher FSC. Leptin as an uremic toxin: Deleterious role of leptin in chronic kidney disease. Biochimie, 2014; 105: 1221.

14. Slee AD. Exploring metabolic dysfunction in chronic kidney disease. Nutr Metabolism (Lond.) 2012; 9(1): 1-8.

15. Davidovich E, Davidovits M, Schwarz Z, Bimstein E, Eidelman E. Pathophysiology, Therapy, and oral implications of renal failure in children and adolescents: An Update. Pediatric Dentistry 2005; 27(2): 98-107.

16. Growth Failure in Children with Chronic Kidney Disease and Urologic Diseases Information Clearinghouse. <http://kidney.niddk.nih.gov/kudiseases/pubs /childkidneydiseases.> (13 April 2015).

17. IDAI (Indonesia Pediatric Society). Kurva Pertumbuhan. 2013< http://idai.or.id/ pro-fessionalresources/growth-chart/kurva-pertumbuh-anwho.html.> (13 April 2015).

18. Training D, Training G, Faculty IM. Relationship between Leptin, Insulin Resistance, Insulin-like Growth Factor-1 and Insulin-like Growth Factor Binding Protein-3 in Patients with Chronic Kidney Disease. J Int Med Res. 2008; 36(3): 522-8.

19. Widiana IG, Kandarini Y, Suwitra K. Hubungan Antara Kadar Leptin dan Adiponektin Plasma pada Pasien dengan Dialisis Rutin. J Penyakit Dalam, 2008; 9(2): 119-21.

20. Zhang, Jingjing, Wang N. Leptin in chronic kidney disease: a link between hematopoiesis, bone metabolism, and nutrition. Int urol Nefrol. 2014; 46(6): 1169-74.

21. Kaur S, Singh NP, Thakur A. Serum C-reactive protein and leptin for assement of nutritional status in patients on maintenance hemodialysis. Indian $\mathbf{J}$ Nephrol. 2012; 22(6): 419-23. 